\title{
Metabolism of the three stereoisomers of 2,6-diaminopimelic acid by rumen microorganisms
}

\author{
AM El-Waziry 1, RM Amin 1, JR Ling 2, Y Tomita 1, R Onodera 1 \\ 1 Laboratory of Animal Nutrition and Biochemistry, Miyazaki University, Miyazaki Shi, 889-21, Japan \\ 2 Institute of Biological Sciences, The University of Wales, Aberystwyth, United Kingdom
}

\begin{abstract}
Most of gram-negative and gram-positive bacteria contain 2,6-diaminopimelic acid (DAP) as a component of their peptidoglycans in cell walls. DAP has been studied in the rumen ecosystem both as a marker of bacterial biomass (Hutton et al, 1971, Br J Nutr, 25, 165173) and as a precursor of lysine production by rumen protozoa (Onodera and Kandatsu, 1973, Nature New Biol, 244, 31-32; Onodera et al, 1974, Agric Biol Chem, 38, 921-926). These were confirmed by Masson and Ling (1986, J Appl Bacteriol, 60, 341-349). However, it is not yet clarified which types of stereoisomers of DAP (DAP-SI) can be converted to lysine by rumen protozoa and bacteria. In the present study, we planned to examine the metabolism of the three DAP-SI by mixed rumen protozoa and bacteria to reveal the type of DAP-SI convertible to lysine.
\end{abstract}

At first, a standard solution of DAP (mixture of three stereoisomers, Sigma) was disolved in buffer solution (MB9) containing no microbes and incubated for up to $12 \mathrm{~h}$ at $39^{\circ} \mathrm{C}$ with antibiotics $(0.1 \mathrm{mg} / \mathrm{ml}$ each of chloramphenicol, streptomycin sulfate and penicillin $G$ potassium) and with and without sterilization treatment of MB9 and all tools to be used to check the stability of DAP-SI under the cultural conditions. Rumen microorganisms were collected from fistulated goats (Japanese native breed), and the suspensions of mixed protozoa $(P)$ and mixed bacteria $(B)$ were prepared and anaerobically incubated with and without DAP $(5 \mathrm{mM}$, mixed DAP-SI ; less than $1 \mathrm{mM}$, individual DAP-SI) for up to $12 \mathrm{~h}$ at $39^{\circ} \mathrm{C}$ using sterilized MB9 and tools. All incubations contained $0.5 \mathrm{mg} / \mathrm{ml}$ rice starch. Samples $(1 \mathrm{ml})$ of the incubations were collected at 0,6 and $12 \mathrm{~h}$, deproteinized with trichloroacetic acid (TCA) and centrifuged at $27000 \times \mathrm{g}$ for $20 \mathrm{~min}$. The supernatant was extracted three times with diethyl ether in a separating funnel to remove TCA and evaporated to remove diethyl ether. Bacterial sediment was hydrolysed with $6 \mathrm{M} \mathrm{HCl}$. All samples were analysed for DAP-SI and lysine by HPLC (El-Waziry et al, 1994, VIIlth ISRP). Three DAP-SI dissolved in MB9 showed no changes during $12 \mathrm{~h}$ incubation at $39^{\circ} \mathrm{C}$ under sterile conditions. Under unsterilized conditions, however, $11.6,6.80$ and $6.20 \%$ (against total DAP) of meso-, LL- and DD-DAP, respectively, were broken down.

in P suspensions, DAP-SI (mixture) decreased by $0.52 \mathrm{mM}(10.59 \%)$ and was converted mainly to $0.41 \mathrm{mM}$ lysine $(8.35 \%)$ after $12 \mathrm{~h}$ incubation under sterile conditions. The remainder $(0.11 \mathrm{mM}, 2.24 \%)$ of DAP may have been converted to an undetermined compound like pipecolic acid as an end product of lysine. When meso-, LL- and DDDAP were added singly to the media, the preliminary results showed that mixed rumen protozoa have an ability to synthesize lysine from meso-DAP and also from DD- and LLDAP probably via a meso-DAP intermediate. This is the first demonstration showing the synthesis of lysine from three DAP-SI by mixed rumen protozoa.

In B suspensions, the added DAP-SI (mixture) decreased by $0.54 \mathrm{mM}(10.84 \%)$ and was converted to $0.21 \mathrm{mM}$ lysine $(4.22 \%)$ after $12 \mathrm{~h}$ incubation in supernatant plus hydrolysates. The remaining DAP $(0.33 \mathrm{mM}$, $6.63 \%$ ) may have been used for constructing cell walls and converted to undetermined compounds such as acetic and butyric acids and ammonia probably via lysine. When meso-, LL- and DD-DAP were added singly to the media, the preliminary results showed that mixed rumen bacteria have the ability to synthesize lysine from LL- and DD-DAP probably via meso-DAP, this is the first discovery of lysine synthesis from DAP by rumen bacteria. 